\title{
Gain of mass between two profiles of treatments to pigs with Self-Organizing Factors
}

\author{
Silvio Leite Monteiro da Silva, Angelo Herbet Moreira Arcanjo, Lucas da Rocha Pinto, \\ Gabriel Pinto Rosa, Gustavo Henrique de Souza \\ Federal Institute of Science, Technology and Education from Southeast of Minas Gerais, \\ Rio Pomba (MG), Brazil
}

\begin{abstract}
Introduction: Highly-diluted medicines are used in clinical practice to treat many pathologies of pigs [1-4]. This therapeutic tool had its potential for valued use due to the global scenario changing on the restriction to limit of antimicrobial residues in the security feeding and production of foods from animal origin for human consume, especially the meat production [5].
\end{abstract}

The Self-Organizing Factors, also known by Factors of Self Organization (FAO), are a developing method (work in progress), mainly used for humans, who were initially employees in the detoxification of professionals who deal with pesticides [6]. The method had its representative medicines named each every significant stage of the development. The decision core is based on practical experience in clinical medicine by a professionals working group in the Rio de Janeiro City/Brazil [7]. The practical clinical effects obtained with various pathologies and acceptance by patients allowed inspiration of its usage to many professionals from other locals, on a lesser scale, through training courses. From 2007 began holding events open to professionals in the annual frequency related areas [7].

Parallel to the trial and error in the practical development usage of the method, interference sources of clinically identified during the process culminated in a unique setting for manipulation of the medicinal products in clinical usage and research [8], in achievement laboratory studies about possible influences of strong electromagnetic fields in medicine [9] and substances used by patients after treatment. There was an agency organization to coordinate various aspects of development related to the method, its scope was also extended to animals and plants [7].

The main criteria used in selecting the profile and dilution to humans are: behavior, degree of damage and chronicity of the pathological process, and patient's age. This text doesn't purport to detail the dynamics of the criteria decision. The composition is a complex of drugs Kali carbonicum, Antimonium crudum, Mercurius solubilis, Natrum muriaticum, Sulphur, Aurum metallicum and Ammonium muriaticum [10]. The treatment profile is determinant the used order. For human two possible profiles are used, while for animals consider the hypothesis that there is only one appropriate profile for each species.

The identification of the patient's profile with the medication order is a determinant of success in the treatment of the clinical practice in humans and animals. The usage of the opposite profile to humans may be more significantly negative noticeable effects than the animals. The appropriate profile can cause signs of healing process in both, notably in humans. 
This methodology was successful in reversing experimental poisoning by organophosphate insecticides in rats [11]. For creation and company animals, they have been reported to cure diseases of the skeletal system [12], tegumentary system [13] and restoration of health in acute and chronic pathological conditions [14].

Whereas various domestics animals of production weren't tested experimentally to determine the most appropriate profile of the medication order, and this methodology can be applied easily in swine, the objective of this study was to determine the effect of each treatment profile provides to live gain weight for pigs in a farm.

The studies with animals and high dilutions are important for all professionals therefore have a high potential to support scientifically the phenomena and effects that occur with ultra-diluted substances.

Material and Methods: Were used 10 healthy female animals in an availability strains from commercial arrays Agroceres ${ }^{\circledR}$ e DanBred ${ }^{\circledR}$, with $37 \pm 2$ days of age during the nursery stage to recreate individually identified with numbered earrings. All animals were housed in the same pen only. The animals were subject to identical conditions of mash-type commercial ration feeding, management, environment and biosecurity. The animals were born and raised on the premises of the Swine Section of the Department of Animal Science of the IF Sudeste MG Campus Rio Pomba, which has a farm of 35 arrays.

The medication was handled in accordance with the standards of the Brazilian Homeopathic Pharmacopoeia [15] in the establishment duly registered [8] and complexed. The medications are taken care of classics and specific transport and storage of ultra-diluted products. They were transported by state-owned postal service of Brazil (Brazilian Post and Telegraph or CORREIOS) on an urgent basis. It was ensured that the transport box wouldn't go through x-rays with of official company employ at the closing of the package.

The amber glass bottles were packed in aluminum envelopes completely sealed with no openings or air passage. Finally, the envelopes were placed in a lead-lined bag (Hama ${ }^{\circledR}$ Film X-Ray Protection Bag), the same used to protect high sensitivity photographic film to airports $\mathrm{x}$-rays. These criteria were established after clinical confirmation of absence or change effects in human patients who transported the medicines in the suitcase for air travel. After we use these criteria, were ceased problems with this drug for patients in these situations.

The animals have always had the mass measured individually and they were blocked by weight into 2 groups of 5 animals each, in the day before the treatment. The medication used 5 globules of each oral dose with a minimum interval of 2 hours or 2 hours and 30 minutes in maximum per animal. Group A $(n=5)$ received $15 \mathrm{cH}, 17 \mathrm{cH}$ e $12 \mathrm{cH}$, group $\mathrm{B}(\mathrm{n}=5)$ received $13 \mathrm{cH}, 12 \mathrm{cH}$ e $17 \mathrm{cH}$, according to the FAO method and triad Archeus medicines. This modality uses three doses and determinants of the profile in this order are the second and third doses. The criterion is if the second is more or less diluted than the third. The first dose is to assist and its own dilution should be numerically close to the second dose and between in relation to the third and the second one. This means that the core of this requirement is the second and third dose and that, although the first dose is different for both groups, the protocols are exactly opposite profiles for one over the other.

The trial lasted 12 weeks, between the months October and January, and 6 procedures were performed for measuring mass (weight) of animals in intervals of two weeks on average, at the same time. The main point for using this age group for this study, has a reason even the beside the weight gain factor, rather the characteristic of the creation and management of swine occurs in stages and different locations. After the period mentioned, the facilities of the institution of the next phase where the animals were offered no stability conditions of biosecurity for scientific data safely. 
The values obtained in group A were compared by test $t$ with the measurements in group B in the same day. All the statistical calculations were performed using the GraphPad InStat v. 3:06, 2003.

This experiment strictly comply with the Brazilian National Council for Animal Research Control (CONCEA) [16].

Figure 1. Detail of the presentation of the medicine globules.
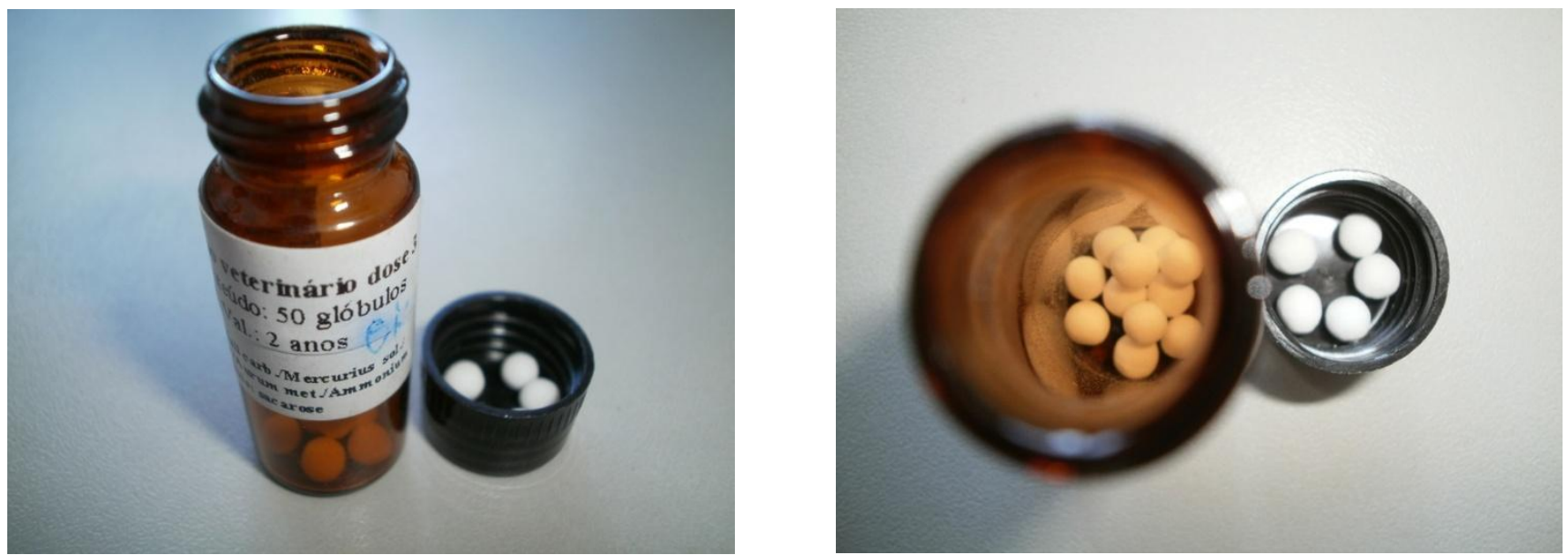

Figure 2. Animals and installation used.
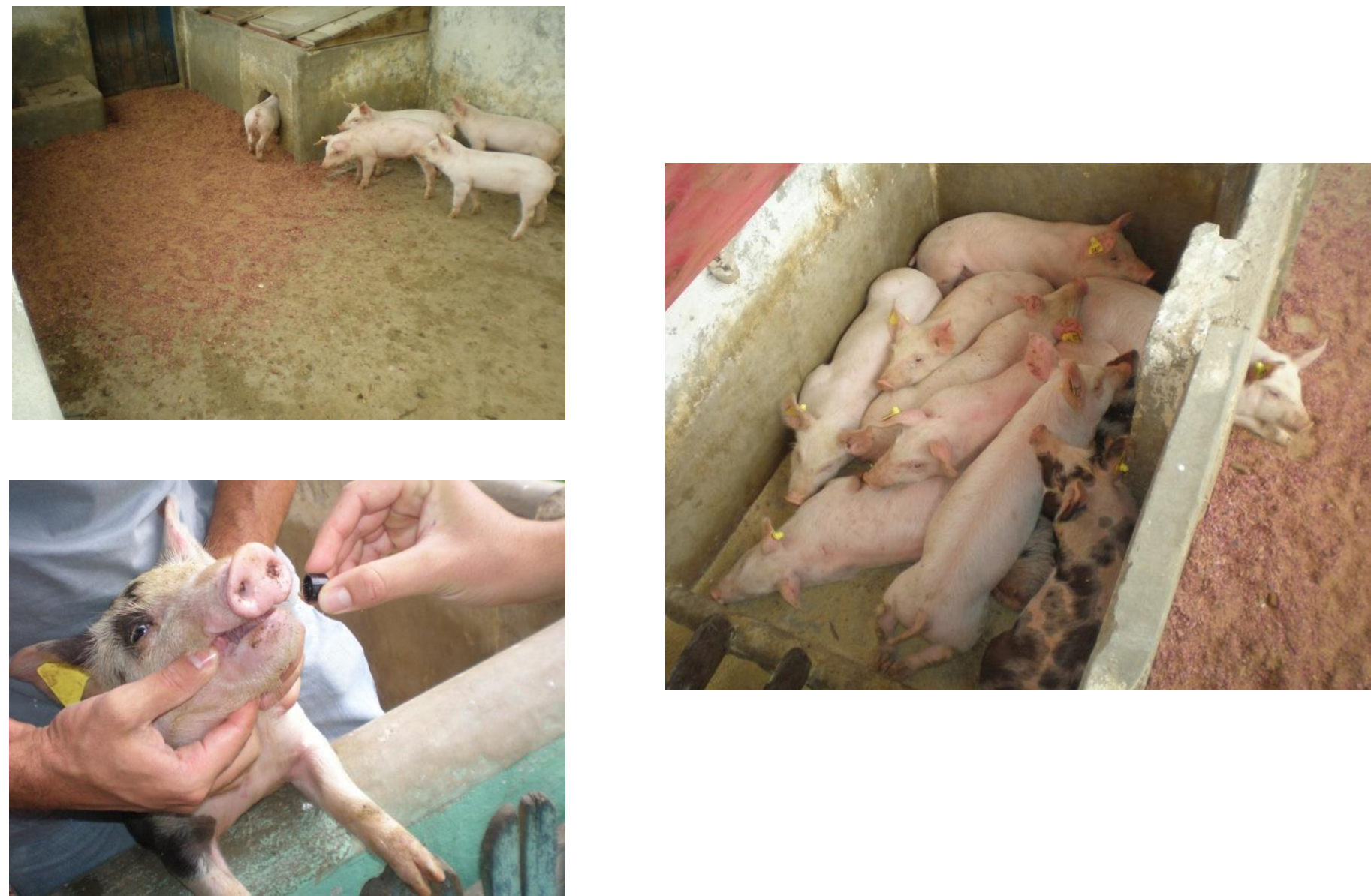
Figure 3. Flasks and medicines transportation packaging used.
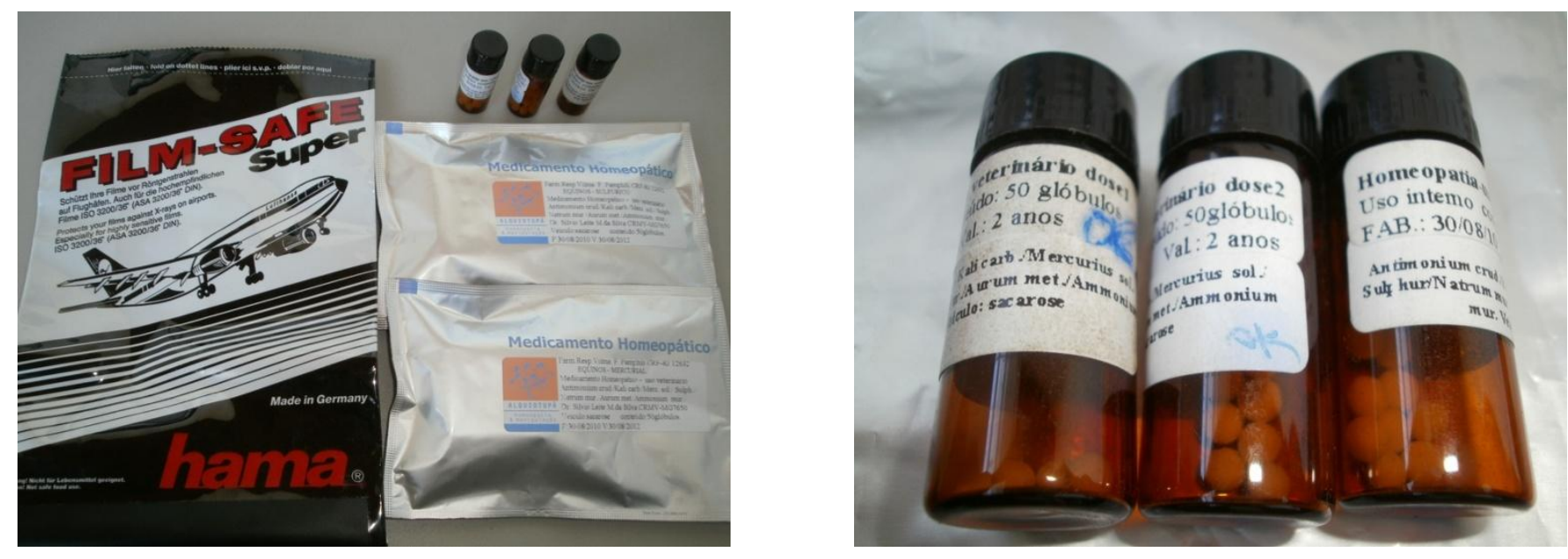

Results: The 6th mass measurement procedure had a mean and standard deviation of $45.800 \pm 5.012 \mathrm{Kg}$ and $56.520 \pm 9.013 \mathrm{Kg}$ for groups $\mathrm{A}$ and $\mathrm{B}$ respectively, and differences between groups, $\mathrm{P}<0.05$ ( $\mathrm{P}$ value $=0,0486$ ) considered significant. The difference between the standard deviation wasn't significant considered with $\mathrm{P}$ value $>0.05(\mathrm{P}$ value $=0.2820)$

The measurements taken before treatment and 1 st to 5 th chronologically occasions showed no significant difference with $\mathrm{p}$-values $>0.05(\mathrm{p}$-value $=0.5818, \mathrm{p}=0.3785, \mathrm{p}=0.4555, \mathrm{p}=0.1570, \mathrm{p}=2.281, \mathrm{p}=0.0921$ respectively). There weren't identified behavioral abnormalities or clinical symptoms typical of individuals worthy of notes between the groups.

Graphic 1: Mass aferition and $p$ values, $t$ test.

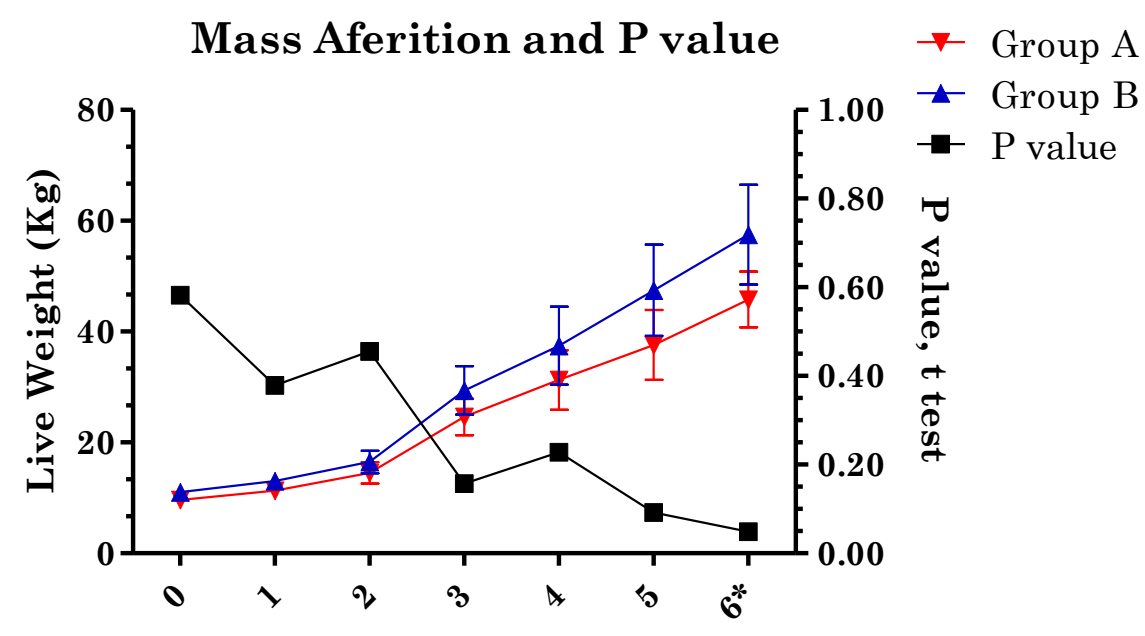

Aferition stages ( 2 weeks on average) 
Table 1: Live weigh (mass) afferition by chronological order. Afferition "0" is before the treatment.

\begin{tabular}{l|c|c|c|c|c|c|c}
\hline & 0 & 1 & 2 & 3 & 4 & 5 & $6^{*}$ \\
\hline Group A (n=5) & $9.6 \pm 1.2$ & $11.2 \pm 1.4$ & $14.5 \pm 1.9$ & $24.6 \pm 3.2$ & $31.3 \pm 5.4$ & $37.6 \pm 6.3$ & $45.8 \pm 5.0$ \\
\hline Group B (n=5) & $10.0 \pm 1.1$ & $12.1 \pm 1.1$ & $15.5 \pm 2.0$ & $28.4 \pm 4.3$ & $36.4 \pm 7.0$ & $46.5 \pm 8.2$ & $56.5 \pm 9.0$ \\
\hline \multirow{2}{*}{ p-value (t test) } & $\mathrm{P}>0.05$ & $\mathrm{P}>0.05$ & $\mathrm{P}>0.05$ & $\mathrm{P}>0.05$ & $\mathrm{P}>0.05$ & $\mathrm{P}>0.05$ & $\mathrm{P}<0.05$ \\
& $(0.5818)$ & $(0.3785)$ & $(0.4555)$ & $(0.1570)$ & $(0.2281)$ & $(0.0921)$ & $(0.0486)$ \\
\hline Significance & no & no & no & no & no & no & yes \\
\hline
\end{tabular}

* Significance $\mathrm{P}<0,05$

Discussion: The usage of this method is compatible in theory with the residue level in foods of animal origin according to the literature, since all medicines are high diluted. In an unprecedented way, it was confirmed there is action for pigs, in addition to those reported for use with other animal species. This information is surprising considering that the method was initially developed for use in humans.

The evolution of the method has several characteristics consistent with the concept of action-research with the reference of medical clinical practice [17]. The FAO development began with the usage of single dose of Sulphur, it passed through two serial repetition with 25 administrations of the seven medicaments in a particular order [10]. They are now three doses with the seven complexed medicaments in a single flask for each dose. The historical reference of how the seven medicaments were discovered inspired by the indian traditional medicine, by the consensual centers of consciousness and by the old chemistry, and beyond the evolution of the order used on the basis of clinical practice up to 2005 are well described [10].

The advantage of using the FAO method triad Archeus medicines is the potential to provide phenomena compatible with the healing process in a single treatment protocol with three doses of the compound, administered in a single day in interval 2 hours between doses and whose effects can last at least from two months up to one year or more. Disadvantages are possible interference which demand changing routine for people who are exposure to relatively common factors like products with camphor or menthol, identified during the treatment by clinical practicing. These factors may be rarely encountered in exposure routine to farm animals.

The difference in size of animals during the growing, had caught students' attention during the experimental period. But this information remained unavailable for later data analysis. The period used for the experiment was determined by the availability of adequate conditions for research and stability management of the farm to the phases used. Initially it wasn't known if the specified period would be sufficient to demonstrate a significant effect due to the lack of reports of this method for scientific observation of animal production.

Even after the trial period, the termination phase, the mass of the animals was measured to monitor, however, less frequently. In this occasion, there was potential interfering factors as expected, that neutralized the rigor needed for research. At slaughter, no significant differences between groups with $\mathrm{P}$ value $>0.05$ (data not shown) and the cause couldn't be determined due to the conditions presented. Therefore, the data were disregarded. The objective of this study doesn't address to determine about the economic viability of the productive usage on this method or medicines.

However, the parameter slaughter weight was reported with no significant difference in another experiment [2], and indeed may not be the best indicator of outcome in a swine herd. While the relationship ending / sow / 
year considers the survival rate and can adequately demonstrate the potential that homeopathic medicines can offer these systems to be a key indicator of the global result but requires controlled conditions over the full productive cicle.

The heaviest animal in the group A $(53.5 \mathrm{~kg})$ presented to the animal equivalent mass lighter than Group B $(52.4 \mathrm{~kg})$, which can occur in the normal distribution. By inference to the results, it suggests that the hypothesis that the pigs used in this study have only one profile may be true. However, the second hypothesis that both treatment profiles can provide weight gain can't be ruled out. That's because this phenomenon can occur at low frequency used and the number utilized don't provide sufficiently sample. If the second hypothesis is true, even it 's low frequency, its application must be assessed in precise delineation of the medication for usage as profile B.

Conclusion: Through the evidence of mass measurement, the usage profile of group B treatment shown to work with pigs and give greater weight live gain in group A during the available trial. Future studies should be conducted with larger numbers of animals to confirm the incidence of the unique profile, with replications to assess the complete production cycle, including the relationship ending / sow / year. Finally, other scales and dilutions should be analyzed to adjust for best answer from the best treatment effect profile.

Keywords: Self-Organizing Factors; Swin, Animals, Live growth rate

Support: We had full access to all the data in this study and we take complete responsibility for the integrity of the data and the accuracy of the data analysis. The authors thank to National Council for Scientific and Technological Development (CNPq) and IF Sudeste MG Campus Rio Pomba for fellowships, to Miria de Amorim for contributions about the dilution, Instituto FAO do Brasil and Farmácia Alquiotupã that kindly offered the used medicines.

\section{References:}

[1] Macleod G. Pigs: the homeopathic approach to the treatment and prevention of diseases. 1st ed. London(UK): C.W.Daniel Co. Ltd; 1994.

[2] Soto FRM, Vuaden ER, Benites RN, Azevedo SS, Pinheiro SR, Bernardi F, Coelho CP, Vasconcellos SA. Implantation of homeopathy and evaluation of productivity indexes in a commercial swine herd compared to allopathic treatment at nursery and fattening stages. Vet. e Zootec. [serial online]. 2007 Jun; 14(1): 107-114. [Portuguese] Available

from: http://www.fmvz.unesp.br/revista/volumes/vol14/Revista\%20v14n01_2007_107_114.pdf

[3] Coelho CP, Soto FRM, Vuaden ER, Melville PA, Oliveira FCS, Benites NR. Evaluation of preventive homeopathic treatment against Colibacillosis in swine production. Int J High Dilution Res. [serial online]. 2009; 8(29): 183-190. Available from: http://www.feg.unesp.br/ ojs/index.php/ijhdr/article/viewFile/361/409

[4] Camerlink I, Ellinger L, Bakker EJ, Lantinga EA. Homeopathy as replacement to antibiotics in the case of Escherichia coli diarrhea in neonatal piglets. Homeopathy. 2010; 99: 57-62. [doi:10.1016/j.homp.2009.10.003]. Available from: http://www.sciencedirect.com/science/article/pii/S1475491609001246

[5] MERCOSUR. Reglamento técnico mercosur metodologías analíticas, ingesta diaria admisible y límites máximos de residuos para medicamentos veterinarios en alimentos de origen animal. Consejo del Mercado Común. 2000; GMC Resolución $\mathrm{N}^{\circ}$ 54/00. [Spanish] Available from: http://www.mercosur.int/msweb/Normas/normas_web/Resoluciones/ES/Res_054_000_RTM_MetodolMedicamentos\%20Veter_Origen\%20Anim_Acta\%203_00.PDF 
[6] Amorim M. The homeopathy in the prevention of the diseases of environmental origin for pesticides: a case study with agricultural and technical engineers. [dissertation] Rio de Janeiro (Brazil): Centro De Ciências da Saúde - CCS, Federal University of Rio de Janeiro; 2003. 110p. [Portuguese] Available from: http://www.fatoresdeautoorganizacao.com.br/antigo/imagens/dissertMestrado.pdf

[7] Amorim M. Instituto FAO do Brasil. Rio de Janeiro (RJ). Copyright: unknown. [updated: unknown; cited 2011 Jun 1] [Portuguese] Available from: http://www.institutofao.com.br

[8] Alquiotupã Manipulação e Homeopatia. [online] Rio de Janeiro (RJ) c2010 [cited 2011 Jun 01] Available from: http://www.alquiotupa.com.br

[9] Moreira Hm, Amorim M, Lazarini Ca, Bignardi F, Tigger J, Ornelas Rh, Oliveira Vm, Biagini M, PachecoFerreira Ha. Possível ação de efeitos deletérios do campo eletromagnético gerado pelo aparelho celular na medicação homeopática. Anais do XXVIII Congresso Brasileiro de Homeopatia; 2006 Sep 3-6; Florianópolis, SC. [CDROM]

[10] Amorim M. Holismo, homeopatia, alquimia: uma sincronicidade para a cura. Holism, homeopathy and alchemy: a Sinchronicity for Healing. 3rd ed. Rio de Janeiro (Brazil): Caravansarai; 2006. [Portuguese]

[11] Moreira HM, Amorim M, Treiger J, Lazarini CA, Ferreira HP, Bignardi F, Biagini M. Reversal of experimental poisoning by organophosphate pesticides in rats with homeopathic medicine. Brazilian Homeopathic Journal. [serial online]. 2008; 10(1): 1-7. [Portuguese] Available from: http://www.ihb.org.br/BR/docs/revista/v.10.n.1-2008/pdf/p.1-7,BHJ,10(1),2008.pdf

[12] Monteiro da Silva SL, Goloubeff B. Resolução clínica de casos opostos: tratamento de osteomielite e anquilose vertebrais em cães com Fatores de Auto-Organização. IX Simpósio Nacional de Pesquisa em Homeopatia; 2008 May 1-3, Rio de Janeiro (Brazil). [Portuguese]

[13] Goloubeff B, Monteiro da Silva SL. Dermatopatias caninas tratadas com Fatores de Auto-organização. Anais do XXIX Congresso Brasileiro de Homeopatia; 2008 Sep 17-21, São Paulo (Brazil). CD-ROM. [Portuguese]

[14] Monteiro da Silva Sl, Goloubeff B. Fatores de Auto-organização em animais. Anais do $4^{\circ}$ Congresso Brasileiro de Homeopatia Veterinária; 2009 Sep 29-Oct 2; Campo Grande (Brazil). CD-ROM. [Portuguese]

[15] Farmacopéia Homeopática Brasileira. 2nd ed. São Paulo (Brazil): Atheneu Editora; 1997. [Portuguese]

[16] BRASIL. Lei $\mathrm{n}^{\circ}$ 11.794, de 8 de outubro de 2008. Regulamenta o inciso VII do $\S 1$ o do art. 225 da Constituição Federal, estabelecendo procedimentos para o uso científico de animais; revoga a Lei no 6.638, de 8 de maio de 1979; e dá outras providências. Diário Oficial [da] República Federativa do Brasil. 196th ed. 2008 Oct 9; Seção 1. [Portuguese] Available from: http://planalto.gov.br/ccivil_03/_Ato20072010/2008/Lei/L11794.htm

[17] Tripp D. Action research: a methodological introduction. Educ. Pesqui. [serial online]. 2005 Sep-Dec; 31(3):443-466 [Portuguese] Available from: http://www.scielo.br/pdf/ep/v31n3/a09v31n3.pdf 


\section{Ganho de massa entre dois perfis de tratamentos para suínos com Fatores de Auto-organização}

\section{RESUMO}

Introdução: Medicamentos ultra-diluídos são utilizados na prática clínica no tratamento de diversas patologias de suínos [1-4]. Esta modalidade terapêutica teve seu potencial de utilização valorizado devido à mudança do cenário mundial sobre limite de resíduos de antimicrobianos na segurança alimentar e produção de alimentos de origem animal para consumo humano, especialmente a produção de carne [5].

Os Fatores de Auto-organização (FAO) são um método em desenvolvimento (work in progress), principalmente utilizado para humanos, que foram inicialmente empregados na desintoxicação de profissionais que lidam com pesticidas [6]. O método possui medicamentos com nomes representativos a cada etapa significativa do desenvolvimento. O núcleo de decisões é baseado na experiência prática de clínica médica por um grupo de profissionais que atuam na cidade do Rio de Janeiro [7]. Os efeitos clínicos práticos obtidos com diversas patologias e a aceitação por pacientes possibilitaram a ampliação de sua utilização para profissionais de outros locais, relativamente em menor escala, através de cursos para capacitação. A partir de 2007 iniciou-se a realização de evento aberto de freqüência anual para profissionais das áreas correlatas [7].

Paralelamente ao desenvolvimento prático de utilização do método por tentativa e erro, fontes de interferência clinicamente identificadas durante o processo culminaram na criação de estabelecimento exclusivo para manipulação dos medicamentos de uso clínico e de pesquisa [8], na realização de estudos em laboratório sobre possíveis influências de campos eletromagnéticos fortes nos medicamentos [9] e substâncias utilizadas pelos pacientes após os tratamentos. Houve a organização de uma entidade para coordenar diversos aspectos de desenvolvimento relacionado ao método, além disso seu escopo foi ampliado para animais e vegetais [7].

Os principais critérios utilizados na escolha do perfil e diluição para humanos são: comportamento, grau de lesão e cronicidade do processo patológico, e idade do paciente. Este texto não se propõe a detalhar a dinâmica de decisões destes critérios. A composição é um complexo dos medicamentos Kali carbonicum, Antimonium crudum, Mercurius solubilis, Natrum muriaticum, Sulphur, Aurum metallicum e Ammonium muriaticum [10]. O perfil de tratamento é determinante para a ordem utilizada. Para humanos são utilizados dois perfis possíveis, enquanto que para animais consideramos a hipótese de que exista apenas um perfil adequado por espécie.

A identificação do perfil do paciente com a ordem da medicação é um fator determinante do sucesso no tratamento da prática clínica em humanos e animais. A utilização do perfil inverso para humanos pode apresentar efeitos negativamente muito mais significativos e perceptíveis em relação aos animais. A utilização do perfil adequado pode provocar sinais de processo de cura em ambos, notoriamente em humanos.

Esta metodologia obteve sucesso na reversão de intoxicação experimental por organofosforado em ratos [11]. Para animais de criação e companhia foram relatados casos com cura de patologias do sistema ósseo [12], tegumentar [13] e restabelecimento da saúde em situações patológicas agudas e crônicas [14].

Considerando que os diversos animais domésticos de produção não foram testados experimentalmente para determinação do perfil mais adequado da ordem da medicação, e que esta metodologia pode ser aplicada com facilidade na suinocultura, o objetivo deste estudo foi determinar o efeito que cada perfil de tratamento proporciona ao ganho de peso vivo para suínos em uma granja. 
Os estudos com animais e ultra-diluições são importantes para todos os profissionais da área, pois, apresentam alto potencial para respaldar cientificamente os fenômenos e efeitos que ocorrem com substâncias ultra-diluídas.

Material e Métodos: Foram utilizados 10 animais fêmeas saudáveis por disponibilidade provenientes de linhagens de matrizes comerciais Agroceres ${ }^{\circledR}$ e DanBred ${ }^{\circledR}$, com $37 \pm 2$ dias de idade durante as fases de creche até recria, identificados individualmente com brincos numerados. Todos os animais foram alojados exclusivamente na mesma baia. Foram de submetidos às condições idênticas de alimentação comercial farelada, manejo, ambiência e biosseguridade. Todos nascidos e criados nas dependências da Seção de Suinocultura do Departamento de Zootecnia do IF Sudeste MG - campus Rio Pomba, que dispõe de uma granja de 35 matrizes.

A medicação foi manipulada de acordo com as normas da Farmacopéia Homeopática Brasileira [15] em estabelecimento registrado [8] e complexada. Os medicamentos receberam cuidados clássicos e específicos para transporte e armazenagem de produtos homeopáticos. Foram transportados pela empresa estatal de serviços postais do Brasil (Empresa Brasileira de Correios e Telégrafos ou Correios) em caráter de urgência. Foi assegurada que a caixa de transportes não passaria por raios-x com a presença de funcionário da empresa no momento do fechamento do pacote.

Os frascos de vidro âmbar foram embalados em envelopes de alumínio completamente lacrados sem aberturas nem passagem de ar. Finalmente, os envelopes foram acondicionados em uma bolsa revestida de chumbo (Hama ${ }^{\circledR}$ Film X-Ray Protection Bag), a mesma utilizada para proteção de filmes fotográficos de alta sensibilidade a raios-x de aeroportos. Estes critérios foram estabelecidos após constatação clínica de ausência ou alteração de efeitos em pacientes humanos que levavam medicamentos na mala durante transportes aéreos. Após a utilização destes critérios cessaram os problemas com efeitos do medicamento para pacientes nestas situações.

Os animais tiveram sempre a massa aferida individualmente e foram distribuídos em blocos por peso em 2 grupos de 5 animais cada, no dia anterior ao tratamento. A medicação utilizou 5 glóbulos de cada dose via oral com intervalo mínimo de $2 \mathrm{~h} 00$ e máximo de $2 \mathrm{~h} 30$ por animal. O grupo A (n=5) recebeu $15 \mathrm{cH}, 17 \mathrm{cH}$ e $12 \mathrm{cH}$, o grupo $\mathrm{B}(\mathrm{n}=5)$ recebeu $13 \mathrm{cH}, 12 \mathrm{cH}$ e $17 \mathrm{cH}$, de acordo com o método FAO e medicação tríade Archeus. Esta modalidade utiliza três doses e os determinantes do perfil nesta ordem são a segunda e terceira doses. O critério é se a segunda é mais ou menos diluída que a terceira. A primeira dose é auxiliar e sua diluição deverá ser numericamente próxima à segunda dose e intermediária em relação à terceira dose. Isto quer dizer que o núcleo desta prescrição é a segunda e terceira dose e que, apesar da primeira dose ser diferente para ambos os grupos, os protocolos são para perfis exatamente opostos um em relação ao outro.

O período experimental durou 12 semanas, entre os meses outubro e janeiro, e foram realizados 6 procedimentos de aferição de massa (peso vivo) dos animais com intervalos de 2 semanas em média, no mesmo horário. O motivo de utilização desta faixa etária para o estudo é porque, além do fator ganho de peso, a característica da criação e manejo da suinocultura ocorre em fases e locais diferentes. Após o período citado, as instalações da instituição da próxima fase para onde os animais foram não ofereciam condições de estabilidade da biosseguridade para obter dados científicos com segurança.

Os valores obtidos do grupo A foram comparados através do teste t sempre com as aferições do grupo B do mesmo dia. Todas os cálculos estatísticos foram realizadas através do programa GraphPad InStat v. 3.06, 2003.

Este experimento atende estritamente as normas do Conselho Nacional de Controle de Experimentação Animal - CONCEA [16]. 
Figura 1. Detalhe da apresentação em glóbulos do medicamento.

Figura 2. Detalhe dos animais e instalações utilizados

Figura 3. Frascos de medicamentos, exemplo de embalagens de acondicionamento e transporte utilizados.

Resultados: $\mathrm{O} 6^{\circ}$ procedimento de aferição de massa apresentou média e desvio-padrão de 45,800 $\pm 5,012 \mathrm{Kg}$ e $56,520 \pm 9,013 \mathrm{Kg}$ para os grupos A e B respectivamente, e diferença entre os grupos, $\mathrm{P}<0,05$ (valor de $\mathrm{P}=0,0486$ ) considerada significativa. A diferença entre os desvios-padrão foi considerada não significativa com valor de $\mathrm{P}>0,05$ (valor de $\mathrm{P}=0,2820$ ).

As aferições realizadas antes do tratamento e da $1^{a}$ à $5^{a}$ ocasiões cronologicamente não apresentaram diferença significativa, com valores de $\mathrm{P}>0,05$ (Valor de $\mathrm{P}=0,5818 ; \mathrm{P}=0,3785 ; \mathrm{P}=0,4555 ; \mathrm{P}=0,1570 ; \mathrm{P}=2281$; $\mathrm{P}=0,0921$ respectivamente). Não foram observadas alterações clínicas ou comportamentais típicas de sintomas particulares dignos de notas entre os grupos.

Gráfico 1: Aferições de massa dos grupos e valores de P ao teste t.

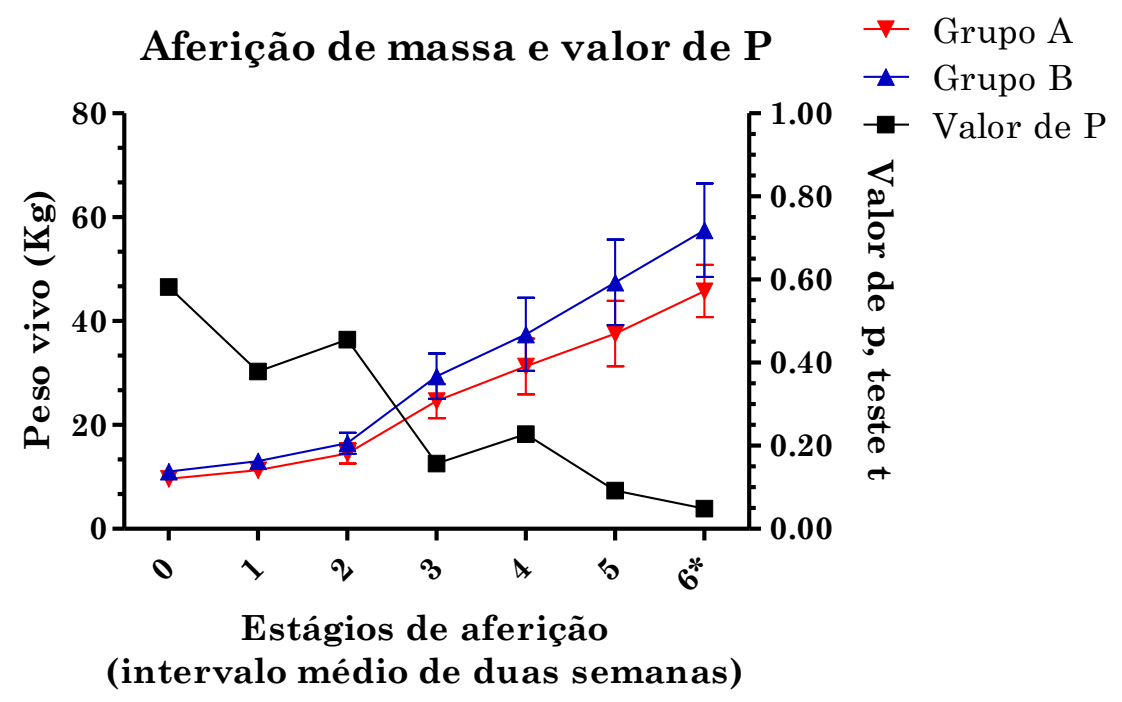

Tabela 1: Peso vivo (aferição de massa) por ordem cronológica. Aferição " 0 " anterior ao tratamento.

\begin{tabular}{l|c|c|c|c|c|c|c}
\hline & 0 & 1 & 2 & 3 & 4 & 5 & $6^{*}$ \\
\hline Grupo A (n=5) & $9.6 \pm 1.2$ & $11.2 \pm 1.4$ & $14.5 \pm 1.9$ & $24.6 \pm 3.2$ & $31.3 \pm 5.4$ & $37.6 \pm 6.3$ & $45.8 \pm 5.0$ \\
\hline GrupoB (n=5) & $10.0 \pm 1.1$ & $12.1 \pm 1.1$ & $15.5 \pm 2.0$ & $28.4 \pm 4.3$ & $36.4 \pm 7.0$ & $46.5 \pm 8.2$ & $56.5 \pm 9.0$ \\
\hline \multirow{2}{*}{ Valor p (t test) } & $\mathrm{P}>0.05$ & $\mathrm{P}>0.05$ & $\mathrm{P}>0.05$ & $\mathrm{P}>0.05$ & $\mathrm{P}>0.05$ & $\mathrm{P}>0.05$ & $\mathrm{P}<0.05$ \\
& $(0.5818)$ & $(0.3785)$ & $(0.4555)$ & $(0.1570)$ & $(0.2281)$ & $(0.0921)$ & $(0.0486)$ \\
\hline Significancia & no & no & no & no & no & no & yes \\
\hline
\end{tabular}

* Significancia $\mathrm{p}<0,05$ 
Discussão: A utilização deste método é teoricamente compatível com os limite de resíduos em alimentos de origem animal de acordo com a literatura, pois todos os medicamentos são ultradiluídos. De forma inédita, foi confirmada que há ação para suínos, adicionalmente aos casos relatados para uso com outras espécies animais. Estas informações são surpreendentes ao considerar que o método foi desenvolvido inicialmente para uso em humanos.

A evolução do método apresenta diversas características compatíveis com o conceito de pesquisa-ação, com o referencial da prática clínica médica [17]. O método FAO começou com utilização de dose única de Sulphur e passou por duas repetições em série com 25 administrações dos sete medicamentos em ordem particular [10]. Atualmente, são três doses de sete medicamentos complexados em único frasco para cada dose. A referência histórica de como os sete medicamentos foram descobertos, inspirados na medicina indiana tradicional, nos centros consensuais de consciência e na química antiga, além da evolução da ordem utilizada com base na prática clínica até 2005 são bem descritos [10].

A vantagem do uso do método FAO medicamento em tríade Archeus é o potencial para proporcionar fenômentos compatíveis com processo de cura em um único protocolo de tratamento com três doses do complexo, ministrados em um único dia no intervaldo de $2 \mathrm{~h}$ entre cada dose e cujos efeitos podem durar de dois meses a mais de um ano. Desvantagens para pessoas são possíveis interferências que demandam alteração na rotina durante o tratamento por exposição a fatores relativamente comuns como produtos com cânfora ou mentol, identificados pela prática clinica. Estes fatores podem estar raramente presentes na rotina de exposição a animais de produção.

A diferença de tamanho dos animais durante o crescimento chamou atenção dos alunos durante o período experimental. Entretanto estas informações permaneceram indisponíveis posteriormente durante a análise dos dados. O período utilizado para o experimento foi determinado pela disponibilidade de condições adequadas para pesquisa e estabilidade do manejo na granja até as fases utilizadas. Inicialmente não se sabia se o período determinado seria suficiente para demonstrar efeito significativo devido à inexistência de relatos da utilização deste método para fins de observação científica com animais de produção.

Mesmo após o período experimental, na fase de terminação, a massa dos animais foi aferida para acompanhamento, entretanto, em menor freqüência. Nesta ocasião, houve fatores com potencial de interferência como esperado que descaracterizam o rigor necessário para pesquisa. Ao abate, não apresentaram diferença significativa entre os grupos com valor de $p>0,05$ (dados não apresentados) e não foi possível determinar a causa devido às condições apresentadas. Portanto, os dados foram desconsiderados. Não é objetivo deste trabalho e seu delineamento não contempla determinar a viabilidade produtiva ou econômica da utilização deste método ou medicamentos.

Contudo, o parâmetro peso ao abate foi relatado com ausência de diferença significativa em outro delineamento experimental [2], e realmente pode não ser o melhor indicador de resultado em uma granja de suínos. Enquanto que a relação terminados/porca/ano considera a sobrevida e pode demonstrar mais adequadamente o potencial que medicamentos homeopáticos podem proporcionar nestes sistemas por ser um indicador chave do resultado global, mas requer condições controladas sobre todo o ciclo produtivo.

O animal mais pesado do grupo A $(53,5 \mathrm{Kg})$ apresentou massa equivalente ao animal mais leve do grupo B $(52,4 \mathrm{Kg})$, o que pode ocorrer na distribuição normal. Por inferência dos resultados, sugere-se de que a hipótese de que os suínos utilizados neste experimento apresentem apenas um perfil possa ser verdadeira. Entretanto, a segunda hipótese de que possam apresentar ganho de peso a ambos os perfis de tratamento não pode ser descartada. Isto porque este fenômeno pode ocorrer em baixa freqüência e o $\mathrm{n}$ utilizado não possibilitar 
amostragem suficiente. Ainda que a segunda hipótese seja verdadeira, mesmo que com baixa freqüência, sua aplicação deve ser avaliada em delineamento específico para utilização da medicação conforme perfil B.

Conclusão: Através das evidências de aferição de massa, o perfil de utilização de tratamento do grupo B demonstrou funcionar com suínos e proporcionar maior ganho de peso vivo em relação ao grupo A durante o período estudado. Futuros trabalhos deverão ser realizados com maior número de animais para confirmação da incidência do perfil único, com repetições que avaliem o ciclo produtivo completo, inclusive a relação terminados/porca/ano. Finalmente, outras escalas e potencias devem ser testados para ajustar a resposta a partir do perfil de tratamento de melhor efeito.

Palavras-chave: Fatores de Auto-organização; Suínos, Animais, Ganho de peso vivo

Suporte: Os autores tiveram acesso completo a todos os dados deste estudo e nos responsabilizamos pela integridade das informações e precisão da análise dos dados. Agradecemos ao Conselho Nacional de Desenvolvimento Científico e Tecnológico ( $\mathrm{CNPq}$ ) e ao IF Sudeste MG campus Rio Pomba pelas bolsas de estudo concedidas, a Miria de Amorim pelas informações sobre diluições, ao Instituto FAO do Brasil e Farmácia Alquiotupã que gentilmente cederam a medicação.

\section{(c)) EY-NC-ND Licensed to GIRI}

Support: CNPq (157341-2010/0), IF Sudeste MG (23222.000523/2010-27).

Conflict of interest: authors declare there is no conflict of interest

Correspondence author: Silvio Leite Monteiro da Silva, silvio.leite@ifsudestemg.edu.br

How to cite this article: Monteiro da Silva SL, Arcanjo AHM, Pinto LR, Rosa GP, Souza GH. Gain of mass between two profiles of treatments to pigs with Self-Organizing Factors. Int J High Dilution Res [online]. 2011 [cited YYYY Month dd]; 10(36): 271-282. Proceedings of the XXV GIRI Symposium and VIII CBFH; 2011 Sep 04-07; Foz do Iguaçu (Brazil). GIRI and ABFH; 2011; Available from: http://www.feg.unesp.br/ ojs/index.php/ijhdr/article/view/501/514 